\title{
(1) Intramedullary Spinal Cord Metastasis in a Patient with Squamous Cell Lung Cancer
}

\author{
Skuamöz Hücreli Akciğer Kanserli Hastada Intramedüller Spinal Kord \\ Metastazı
}

To The Editor,

Intradural and intramedullary spinal cord metastases are rare in squamous cell lung cancer. Herein, we present a case with squamous cell lung cancer developed intramedullary spinal cord metastasis.

A-61-year old man with a history of lung cancer was admitted to our emergency service with a sudden-onset of paraplegia. Cerebral, thoracic, and lumbar magnetic resonance imaging (MRI) was performed due to neurological complaints. Intradural and, intramedullary spinal metastasis was demonstrated at T1A, T2A weighted sagittal images in thoracic region, with leptomeningeal involvement (Figure 1). There was no pathological change in cerebral MRI. Lung squamous cell carcinoma was diagnosed with bronchoscopy five months before emergency admission (Figure 2). Urgent radiotherapy was planned for the treatment.

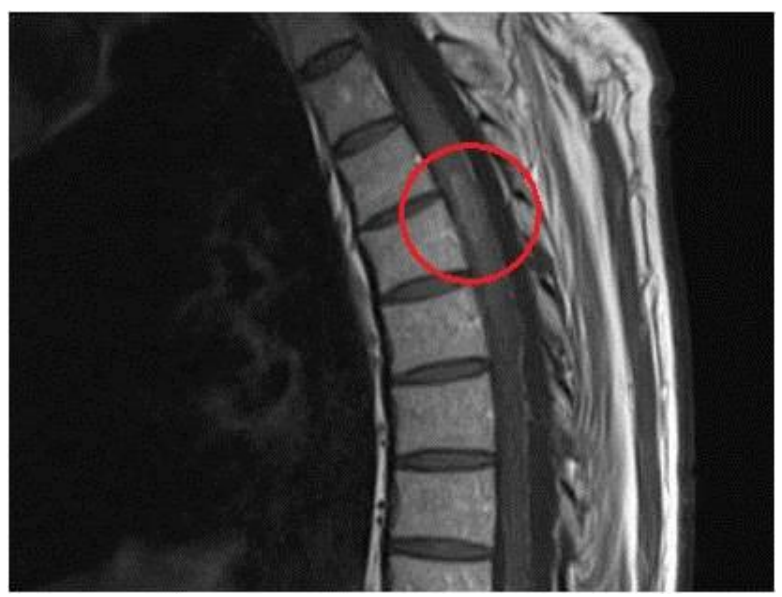

Figure 1: Intradural and, intramedullary spinal metastases demonstrated at TIA, weighted sagittal images in thoracic region $M R I$

Metastases to the spine can involve the bone, epidural space, leptomeninges, and spinal cord. The spine is the third most common site for metastatic disease, following the lung and the liver and the most common osseous site. Approximately 60 to $70 \%$ of patients with systemic cancer have spinal metastasis. Fortunately, only $10 \%$ of these patients are symptomatic $(1,2)$. Intramedullary spinal cord metastasis compromises only 1 to $3 \%$ of all intramedullary spinal cord neoplasms (3). In our case, only intradural and, intramedullary metastases with leptomeningeal involvement were observed and, there were no metastases findings in the other parts of the body. Metastatic intramedullary spinal cord tumors may cause pain, sensory disturbance, weakness, and sphincter dysfunction due to edema, distortion and compression of the spinal cord parenchyma (3). Despite deterioration of neurological status is relatively rapid within a period of days to weeks in intra spinal cord metastases, symptoms typically present a slow progression in primary intramedullary tumors (3). Sudden paraplegia and, sphincter dysfunction occurred in days in our case.

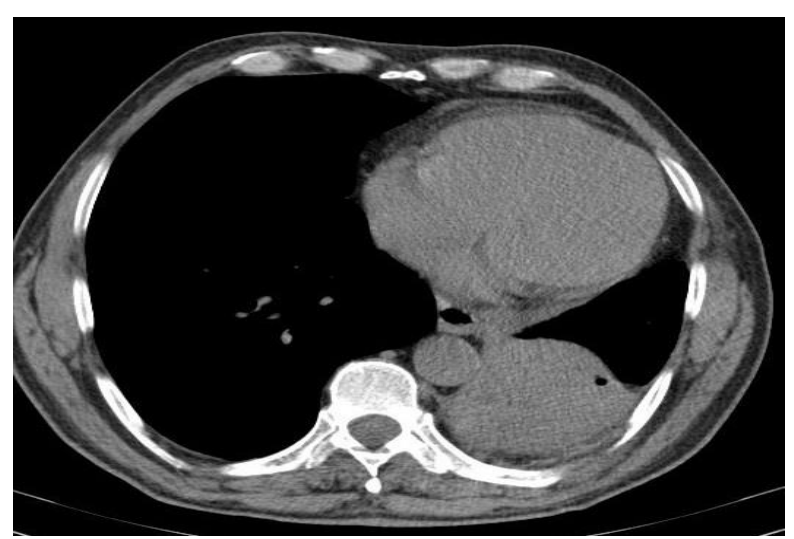

Figure 2: Axial chest CT images showing a large heterogeneous hypodense, well-defined peripheral lung mass with small areas of cavitation in the left lower lobe

In conclusion, despite to the low metastasis rate of lung cancer in spinal cord, intramedullary metastasis should be kept in mind in patients with neurological 
deterioration. Of note, imaging studies play an important role in the diagnosis of spinal metastasis.

Tahir Taha Bekçi ${ }^{1}$, Ramazan Koylu², Mustafa Çalık ${ }^{3}$, Süleyman Baktık ${ }^{4}$, Saniye Göknil Çalık²

'Department of Pulmonary Medicine, Konya Education and Research Hospital, Konya, Turkey

${ }^{2}$ Department of Emergency Medicine, Konya Education and Research Hospital, Konya, Turkey

${ }^{3}$ Department of Thoracic Surgery, Konya Education and Research Hospital, Konya, Turkey

${ }^{4}$ Department of Radiology, Konya Education and Research Hospital, Konya, Turkey

Correspondence (illetişim): Mustafa Çalık, Department of Thoracic Surgery, Konya Education and Research Hospital, Konya, Turkey

e-mail:drmcalik@hotmail.com

\section{CONFLICTS OF INTEREST}

None declared.

\section{AUTHOR CONTRIBUTIONS}

Concept - T.T.B., R.K., M.Ç., S.B., S.G.Ç.; Planning and Design - T.T.B., R.K., M.Ç., S.B., S.G.Ç.; Supervision - T.T.B., R.K., M.Ç., S.B., S.G.Ç.; Funding - T.T.B., M.Ç., S.G.Ç.; Materials - T.T.B., M.Ç., S.G.Ç.; Data Collection and/or Processing - T.T.B.,
M.Ç., S.G.Ç.; Analysis and/or Interpretation - T.T.B. M.Ç., S.G.Ç.; Literature Review - T.T.B., M.Ç., S.G.Ç.; Writing - T.T.B., M.Ç., S.G.Ç.; Critical Review - T.T.B., M.Ç., S.G.Ç.

\section{YAZAR KATKILARI}

Fikir - T.T.B., R.K., M.Ç., S.B., S.G.Ç.; Tasarım ve Dizayn - T.T.B., R.K., M.Ç., S.B., S.G.Ç.; Denetleme - T.T.B., R.K., M.Ç., S.B., S.G.Ç.; Kaynaklar - T.T.B. M.Ç., S.G.Ç.; Malzemeler - T.T.B., M.Ç., S.G.Ç.; Veri Toplama ve/veya İşleme - T.T.B., M.Ç., S.G.Ç.; Analiz ve/veya Yorum - T.T.B., M.Ç., S.G.Ç.; Literatür Taraması - T.T.B., M.Ç., S.G.Ç.; Yazıyı Yazan T.T.B., M.Ç., S.G.Ç.; Eleştirel Inceleme - T.T.B., M.Ç., S.G.Ç.

\section{REFERENCES:}

1. Shah LM, Salzman KL. Imaging of spinal metastatic disease. Int J Surg Oncol 2011; 2011:769753. [CrossRef]

2. Witham TF, Khavkin YA, Gallia GL, Wolinsky JP, Gokaslan ZL. Surgery insight: current management of epidural spinal cord compression from metastatic spine disease. Nat Clin Pract Neurol 2006; 2:87-94. [CrossRef]

3. Klimo P Jr, Schmidt MH. Surgical management of spinal metastases. Oncologist 2004; 9:188-96. [CrossRef] 